\title{
Potential of soil fumigation with mustard essential oil to substitute biofumigation by cruciferous plant species
}

\author{
Onkar D. Dhingra, Daniel A. Schurt, Rosângela D. L. Oliveira \& Fabrício A. Rodrigues \\ Departamento de Fitopatologia, Universidade Federal de Viçosa, 36570-000, Viçosa, MG, Brazil
}

Author for correspondence: Fabrício A. Rodrigues, e-mail: fabricio@ufv.br

\begin{abstract}
Soil fumigation with the synthetic essential oil of mustard ( $93 \%$ allyl isothiocyanate) (EOM) was evaluated as a substitute of bio-fumigation with cruciferous plant species, using Sclerotium rolfsii and Sclerotinia sclerotiorum as test pathogens, together with its non-target effect on the general population of soil microorganisms. The mortality of the sclerotia of both fungi was dependent upon the concentration of EOM and the exposure period. Exposure to the EOM vapors delayed in vitro germination of the sclerotia. Total germination of the control sclerotia of $S$. rolfsii, after $120 \mathrm{~h}$ incubation, was $94 \%$, of which $88 \%$ germinated within $48 \mathrm{~h}$. In contrast, to the total germination of $77 \%$ or $47 \%$, less than $3 \%$ germinated in $48 \mathrm{~h}$ when exposed for 4 or 7 days to $50 \mu 1$ EOM/L. Exposure to $100 \mu 1 / 1$ for 4 or 7 days resulted in the mortality of 50 and $100 \%$ sclerotia, respectively. The tendency for delayed germination and mortality was similar for the sclerotia of $S$. sclerotiorum. No viable sclerotia of either fungus were detected to the depth of $10 \mathrm{~cm}$ in the air dried, moist or wet soil fumigated for 7 days with the EOM at the rate of $150 \mu \mathrm{l} / \mathrm{L}$. In the field plots, no viable sclerotia of $S$. rolfsii were detected after 7-day exposure to the EOM applied to the upper soil layer at the rate of 9, 12, or $18 \mathrm{ml} / \mathrm{m}^{2}$ and covered with a plastic sheet, while 73,50 and $15 \%$, respectively, were recovered from uncovered plots. In field plots, the fluorescein diacetate hydrolysis decreased by EOM treatment. However, the colony forming units of actinomycetes and bacteria increased, but those of fungi decreased significantly. Soil fumigation with EOM can be used with several advantages, as a substitute of bio-fumigation with cruciferous plant species.
\end{abstract}

Key words: Allyl isothiocyanate, flavoring agent, inoculum density, sclerotial fungi, soil fumigant, soil treatment.

Successful production of horticultural crops depends upon the control of soilborne pathogens, which used to be managed by soil fumigation with methyl bromide (MB). The ban on the use of MB resulted in an intensive search for the development of alternative methods of low environmental impact such as the bio-fumigation with the use of green manuring with cruciferous plant species. Plant species commonly used in these studies are cabbage, indian mustard, rape seed, white mustard and oil radish. The fungicidal effect is attributed to the release of volatile isothiocyanates (ITC), thiocyanates and nitriles produced by the enzymatic hydrolysis of glucosinolates present in the plant tissues (Mayton et al., 1996; Bending \& Lincoln, 1999). The efficacy of this green manuring to control soilborne pathogens depends upon the type of volatile compounds released, which depends upon the parental glucosinolate present in the plant tissue.

A variety of ITCs are known to have high fungicidal activity, but allyl isothiocyanate (AITC), produced by the hydrolysis of the glucosinolate sinigrin is among the most active. The degree of fungicidal activity of some Brassica species was highly correlated to the amount of AITC released (Mayton et al., 1996). However, highly fungitoxic glucosinolate hydrolytic products do not accumulate in large amounts in soil, due to insufficient tissue disruption, microbial degradation of tissue cell wall resulting in enzyme inactivation, and microbial degradation of the hydrolytic products (Bending \& Lincoln, 1999). Considering the disadvantages of green manuring and having the knowledge of its mechanism of action, it appears that the direct use of the hydrolytic compounds of the glucosinolates can assure least variable results. The AITC that imparts the characteristic flavor and pungency to indian mustard, wasabi and horse radish, constitutes more than $80 \%$ of the essential oil of mustard (EOM). The EOM can be produced by hydrodistillation of macerated plant tissues or synthesized chemically. The synthesized form generally, contains more than $90 \%$ AITC. Because of the economics and standardization, the synthetic form is used by the food industry as a flavoring agent for pickles and sauces. A very preliminary study showed that drenching seedling production substrates with water containing synthetic EOM effectively controlled Rhizoctonia solani (Dhingra et al., 2004). AITC is highly volatile (3.5 $\mathrm{mmHg}$ vapor pressure), and its vapors are known to be highly fungitoxic. Therefore, the following study was done to determine the potential of synthetic EOM for soil fumigation as a substitute of green manuring with cruciferous plant speceis, to reduce the inoculum density of Sclerotium rolfsii Sacc. and Sclerotinia sclerotiorum (Lib.) de Bary under different soil moisture and temperatures and its effect on the general soil microbial activity. 
The synthetic EOM (93\% AITC) was procured from Bpar Química, São Paulo, Brazil and was diluted with soybean oil $(20 \% \mathrm{v} / \mathrm{v})$ or emulsified with Tween $80^{\circledR}(5 \%$ $\mathrm{v} / \mathrm{v}$ ) for use with water. Only one type of soil texture was used because it did not affect the efficacy of the EOM in controlling $R$. solani (Dhingra et al., 2004). The soil used was a silty-clay ( $41 \%$ sand, $23 \%$ silt, and $36 \%$ clay, $\mathrm{pH} 6.5$, and $2.45 \%$ organic matter). The gravimetric soil moisture was adjusted to 17 (moist soil) or 22\% (wet soil) w/w, corresponding to a matric potential of $-410 \mathrm{kPa}$ and $-278 \mathrm{kPa}$ or 50 and $65 \%$ of the water holding capacity, respectively.

The isolates of $S$. rolfsii and $S$. sclerotiorum were obtained from diseased bean plants. For sclerotia production, both fungi were cultivated on moist autoclaved $\left(30 \mathrm{~min}\right.$ at $\left.121^{\circ} \mathrm{C}\right)$ maize meal:sand mixture $(1: 15)$ in several half-filled 2-liter glass jars. The culture in the jar was shaken at 2-days interval for 10 days to allow for uniform colonization of the substrate and then maintained undisturbed for additional 30 days for production and maturation of the sclerotia (Dhingra \& Sinclair, 1995). The cultures were then spread in a thin layer (about $1.5 \mathrm{~cm}$ ) in plastic trays, covered with an absorbent paper, and allowed to dry at room temperature for 15 days. The sclerotia of $S$. sclerotiorum were separated by sieving through 2-mm sieve and those of $S$. rolfsii were rolled out of the substrate by the use of a laboratory scale vibrating gravity table.

To determine the effect of the EOM vapors on the viability of sclerotia, 500 sclerotia of $S$. rolfsii and 150 of S. sclerotiorum were placed in a $250 \mathrm{ml}$ flask, followed by placing a filter paper strip impregnated with the EOMsoybean oil mixture to provide $50,100,150$, or $200 \mu 1$ of $\mathrm{EOM} / \mathrm{l}$ flask volume. The paper strip impregnated only with soybean oil served as control. The flask was immediately sealed with a rubber stopper and stored for 4 or 7 days at $25^{\circ} \mathrm{C}$. There was a separate flask for each concentration and exposure period. The post-exposure viability of the sclerotia of $S$. rolfsii was determined by the germination test. The sclerotia were placed on sterile moist blotter paper in plastic boxes and incubated at $25^{\circ} \mathrm{C}$. The germination was evaluated at $24 \mathrm{~h}$ interval for $120 \mathrm{~h}$. The viability of $S$. sclerotiorum was tested by incubating the sclerotia for 4 days on potatodextrose-agar $(\mathrm{pH} 4.7)$ amended with bromophenol blue $(150 \mu \mathrm{g} / \mathrm{ml})$ at $25^{\circ} \mathrm{C}$. A sclerotium was considered viable if a yellow halo was formed around it (Peres et al., 2002). A $5 \times 2$ factorial experiment consisting of EOM doses and days of exposure to EOM was arranged in a randomized block design with three replications. Data were subjected to analysis of variance (ANOVA) and presented as the percent cumulative germination of sclerotia of $S$. rolfsii and $S$. sclerotiorum exposed for 4 or 7 days to the EOM rates.

An experiment was done in air-dry, moist and wet soil. The sclerotia of $S$. rolfsii (about 2500) and of $S$. sclerotiorum (about 150) were uniformly mixed with 300 $\mathrm{g}$ soil (dry weight basis) and placed in a $500 \mathrm{ml}$ plastic jar. Drops of EOM-soybean soil mixture supplying EOM dose of 150 or $200 \mu \mathrm{l} / 1$ jar volume were roughly mixed with the about 1-cm top soil, and the jar was closed with its lid. These doses were selected on the bases of the results of the in vitro test. Control consisted of mixing equivalent quantity of soybean oil. The jars with soil were placed for 7 days at 25 or $35^{\circ} \mathrm{C}$. To determine sclerotial viability, soil from each jar was sampled from four locations. A 2-cm diameter corkborer was inserted up to the bottom of the jar (about $10 \mathrm{~cm}$ ) and the soil collected in the cork-borer was retrieved. The four sub-samples were mixed to obtain a sample of the jar. A portion of (about $50 \mathrm{~g}$ ) was allowed to dry in a refrigerator (about $5^{\circ} \mathrm{C}$ ) to determine microbial population, and the remaining portion was used for retrieving the sclerotia. The sclerotia were recovered by wet sieving (Dhingra \& Sinclair, 1995), washed under running tap water, and spread over a blotter paper to dry for about $24 \mathrm{~h}$ on the laboratory bench. The sclerotial viability was tested as described earlier, except that the sclerotia were disinfested by immersion for 30 seconds in $70 \%$ ethanol followed by 30 seconds in sodium hypochlorite solution (1\% active chlorine), and then rinsed in sterile distilled water. The germination was evaluated only after $120 \mathrm{~h}$ of incubation. The fluorescein diacetate (FDA) hydrolysis, an indicator of total microbial activity, was determined according to Schnürer \& Rosswall (1982), and the results were expressed as $\mu \mathrm{g}$ FDA hydrolyzed/g soil (dry weight basis). The colony forming units (CFUs) of actinomycetes and bacteria were determined by plating serial soil dilutions, prepared in saline solution $(0.85 \% \mathrm{NaCl})$, on dextrose-nitrate-agar and nutrient agar-cyclohexamide, respectively (Dhingra $\&$ Sinclair, 1995). There were five plates for each dilution of each treatment and replication. To determine CFUs of fungi, $0.1 \mathrm{ml}$ of the soil suspension (1:9) was mixed with $100 \mathrm{ml}$ of cool molten peptone-rose-bengal-agar (Martin, 1950), and the mixture was distributed into ten 9-cm culture plates. The results were expressed as CFUs/g soil (oven dry weight basis). A $3 \times 3$ factorial experiment consisting of soil moisture and EOM doses was arranged in a randomized block design with three replications. Data were subjected to analysis of variance (ANOVA) and treatment means were compared by the Tukey's test.

An experiment was done to determine the efficacy of EOM, applied through drip irrigation, on the sclerotial mortality at different soil depths. A 20-cm long and 1.5$\mathrm{cm}$ diameter PVC tube was filled with $80 \mathrm{~g}$ of air-dried soil, and the tube was closed at bottom with a nylon cloth to hold the soil, and allow for water dripping. During filling, nylon cloth pouches containing about 150 sclerotia of $S$. rolfsii and 15 of $S$. sclerotiorum were placed at the depths of $18,13,8$, and $2 \mathrm{~cm}$. The soil was then wetted by dripping $40 \mathrm{ml}$ water (water retention capacity) containing emulsified EOM to provide 150 or $200 \mu \mathrm{EOM} / \mathrm{kg}$ soil. The soil wetted with water only served as control. The tubes were capped on both ends and placed in vertical position at $25^{\circ} \mathrm{C}$. The sclerotia carrying pouches were recovered after 7 days and the viability of sclerotia was determined as described previously. A $4 \times 3$ factorial experiment 
consisting of soil depths and EOM doses was arranged in a randomized block design with three replications. Data were subjected to analysis of variance (ANOVA) and treatment means were compared by the Tukey's test.

An experiment was done to determine the potential of EOM to reduce the inoculum density $S$. rolfsii under field conditions, with and without the use of a plastic sheet cover. Before use, the experimental area of about $100 \mathrm{~m}^{2}$ was tilled with a hand tiller to a depth of about $15 \mathrm{~cm}$, and after broadcasting the sclerotia, the area was tilled again to mix them with the soil. The area was then divided into three blocks, which represented the replications. Each block was divided into $2 \times 1 \mathrm{~m}$ plots with $50 \mathrm{~cm}$ inter-plot space. Just before EOM application, soil samples were collected to a depth of about $10 \mathrm{~cm}$, from ten randomly distributed points of the plot with the help of a 2-cm diameter sampler, and pooled to obtain the plot sample. Each sampling site was marked as reference for post-treatment sampling.

The plots were treated with the EOM at the rate of 9,12 , or $18 \mathrm{ml} / \mathrm{m}^{2}$ using water as carrier. To assure uniform application, the emulsified EOM was mixed with 51 of water, which was sprinkled over the plot with use of a garden irrigator. The plot receiving only water served as control. Four plots in each block were covered with a black plastic sheet. After 7-days exposure, soil samples were collected from each plot as described previously, from the marked locations to determine FDA hydrolysis and CFUs of actinomycetes, bacteria, and fungi. The results were expressed as percent change relative to the pretreatment values. To determine sclerotial viability, samples were collected, as described previously, from fifteen randomly distributed points and pooled. The sclerotia were recovered from soil by wet sieving and their viability was tested by incubating 200 disinfested sclerotia, as described previously. A $2 \times 2$ factorial experiment consisting of EOM doses and plastic sheet cover was arranged in a randomized block design with three replications. Data were subjected to analysis of variance (ANOVA) and treatment means were compared by the Tukey's test.

Sclerotia of $S$. rolfsii and S. sclerotiorum started to germinate at $48 \mathrm{~h}$ for both 4 and 7 days for the control treatment (Figure 1A-B). For $S$. rolfsii, sclerotia started to germinate only at 72 when exposed for 4 days to the rate of $100 \mu \mathrm{l} / 1 \mathrm{EOM}$ and when exposed to 7 days the accumulated germination of sclerotia was dramatically lower in comparison to the 4 days of exposure (Figure 1A). For S. sclerotiorum, sclerotia started to germinate at 72 when exposed for 4 days to the rates of 50 and $100 \mu \mathrm{l} / \mathrm{l} \mathrm{EOM}$ (Figure 1B). For the exposure of 7 days, sclerotia started to germinate at 48 and $72 \mathrm{~h}$, respectively, to the rates of 50 and $100 \mu \mathrm{l} / 1 \mathrm{EOM}$ (Figure 1B). The accumulated germination of sclerotia of $S$. sclerotiorum dramatically decreased from 50 to $100 \mu 1 / 1$ of EOM for both 4 and 7 days of exposure (Figure 1B). Sclerotia of S. rolfsii and S. sclerotiorum did not germinate when exposed to the rates of 150 or $200 \mu \mathrm{l} / 1$ EOM for 4 and 7 days (Figure 1A-B).
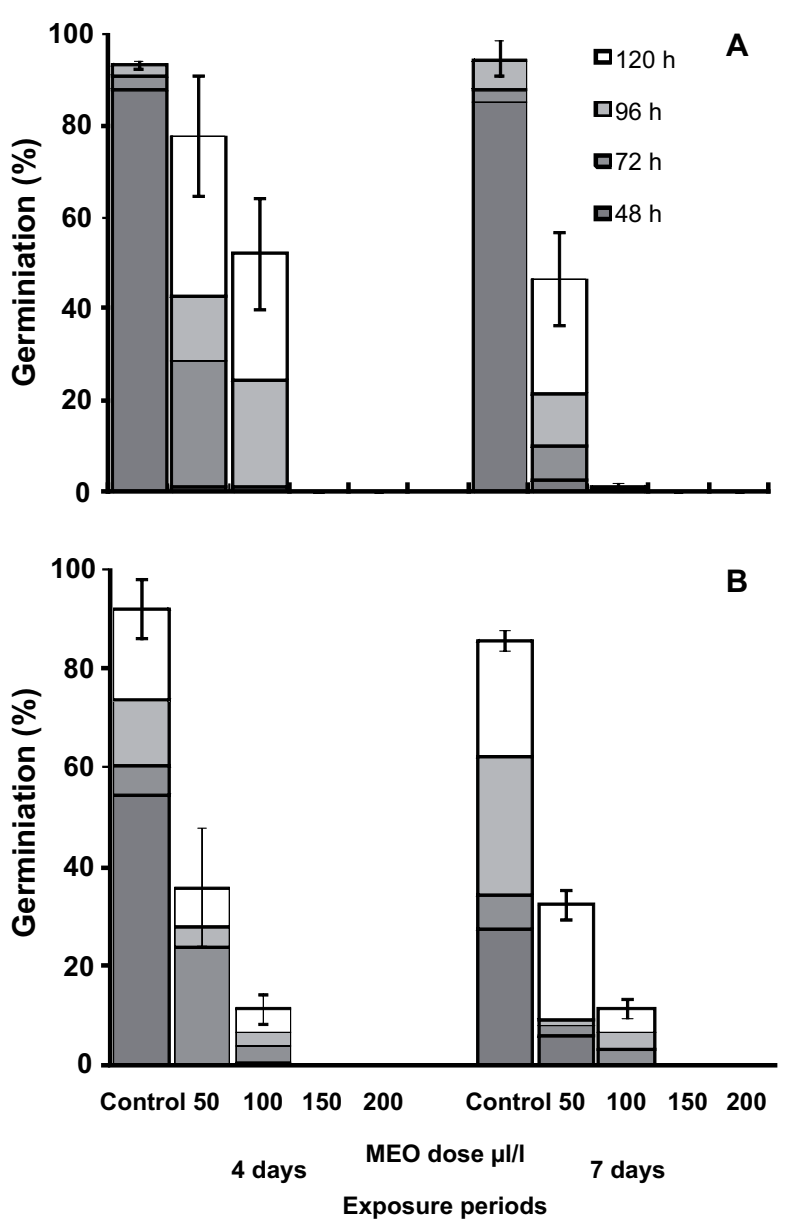

FIGURE 1 - A. Percent cumulative germination of sclerotia of Sclerotium rolfsii B. and Sclerotinia sclerotiorum exposed for four or seven days to the vapors of mustard essential oil at different concentrations. Average of three replications.

Only viable sclerotia of $S$. rolfsii were recovered from moist $(17 \%)$ or wet soils $(30 \%)$ fumigated with 150 $\mu 1 \mathrm{EOM} / 1$ at $25^{\circ} \mathrm{C}$. More than $90 \%$ sclerotia of $S$. rolfsii and $S$. sclerotiorum recovered from non-fumigated soil were viable. There was no interaction between EOM dose and soil moisture or temperature.

The survival rate of the sclerotia of $S$. rolfsii varied between 70 and $85 \%$ in non-treated soil, with no significant difference between depths. In soil treated with dose of $150 \mu \mathrm{l} / \mathrm{kg}$, no sclerotia survived to the depth of $8 \mathrm{~cm}$, while more than $60 \%$ of the sclerotia survived at the depths of 13 and $18 \mathrm{~cm}$. No viable sclerotia were recovered from any depth from soil treated with 200 $\mu 1 / 1$ (Figure 2A). In case of S. sclerotiorum, 50 to $60 \%$ sclerotia at all depths retained viability in non-treated soil with no significant difference between depths. By contrast, in soil treated with the dose of $150 \mu \mathrm{l} / \mathrm{kg}, 10,32$, and $56 \%$ sclerotia survived at the depth of 8,13 , and $18 \mathrm{~cm}$, respectively, with a significant difference between depths. However, in soil treated with dose of $200 \mu \mathrm{l} / \mathrm{kg}$, no sclerotia survived at 2 or $8 \mathrm{~cm}$ soil depths, while at greater depths the 

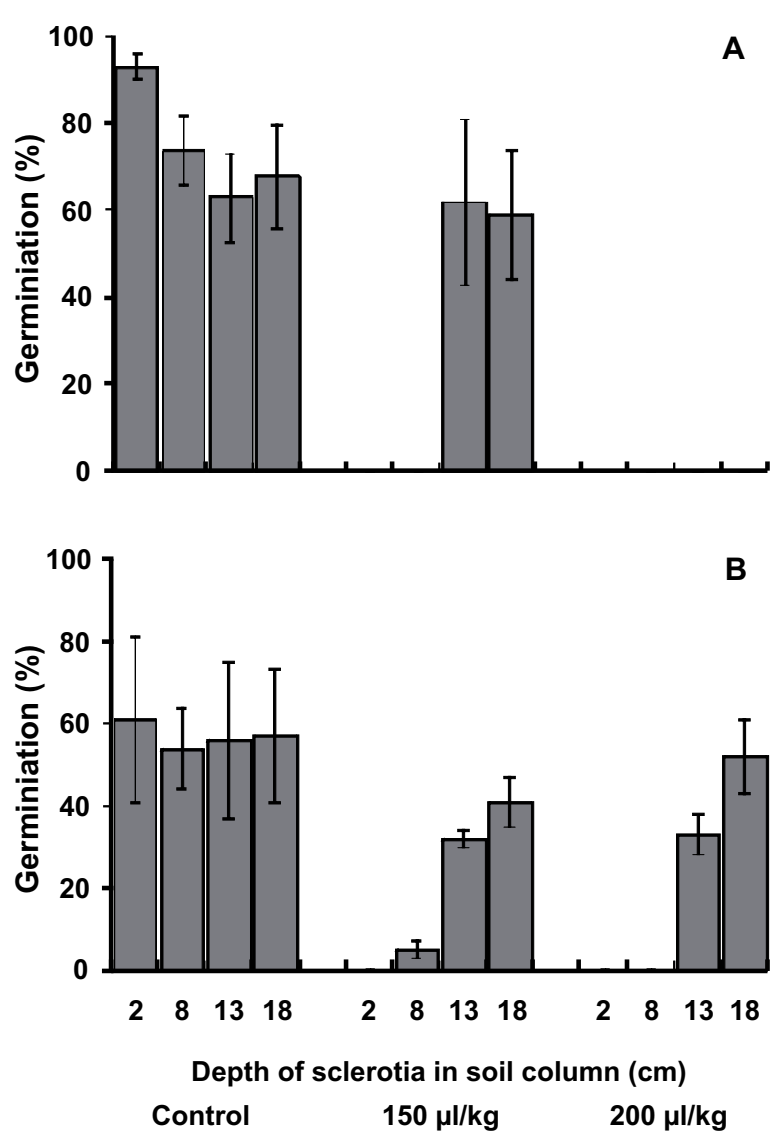

FIGURE 2 - A. Mean percent germination of sclerotia of Sclerotium rolfsii and B. Sclerotinia sclerotiorum recovered after seven days from different depths of a soil column treated with 150 or $200 \mu \mathrm{l} / \mathrm{kg}$ of mustard essential oil applied through drip irrigation until saturation. Average of three replications.

survival rate was similar to the soil treated with the dose of $150 \mu 1 / \mathrm{kg}$ (Figure 2B).

In non-treated plots, 93 to $99 \%$ of the recovered sclerotia were viable with no significant difference between covered and uncovered plots. There as a significant interaction between covering and EOM dose. Less than $2 \%$ sclerotia recovered from covered plots treated with $9 \mathrm{ml} /$ $\mathrm{m}^{2}$ were viable, while no viable sclerotia were recovered from plots treated with higher doses. In contrast 73, 50, and $15 \%$ viable sclerotia were recovered from uncovered plots treated with 9,12 , and $18 \mathrm{ml} / \mathrm{m}^{2}$, respectively.

In the laboratory experiment, the FDA hydrolysis was significantly higher in non-treated moist and wet soils (56.1 \pm 1 and $72.5 \pm 7 \mu \mathrm{g} / \mathrm{g}$ soil, respectively) compared to the dry soil $(49.8 \pm 2 \mu \mathrm{g} / \mathrm{g})$. In the presence of EOM, there was no significant difference between soil moisture contents for FDA hydrolysis (Table1). The CFUs of actinomycetes did not change by EOM treatment in dry soil, but in moist and wet soils, CFUs were 95 to $97 \%$ lower compared to the non-treated soil at the corresponding moisture. The mean bacterial counts did change significantly with the EOM treatment only for the moist soil (Table1). Although the
CFUs of fungi in non-treated soils with different moisture contents differed significantly in treated soil their number, regardless of moisture, did not differ significantly. On average, CFUs of fungi were $98 \%$ lower in EOM treated compared to non-treated soil (Table 1).

In the field plots, total FDA hydrolysis declined regardless of the EOM application and plastic cover, with no significant difference between treatments. The percent decline varied between $23 \pm 12$ and $38 \pm 8$ in covered plots and between $20 \pm 8$ and $40 \pm 9$ in non-covered plots (Table 2). In non-treated plots, the CFUs of actinomycetes increased, from the initial level, by $222 \%$ in covered and $120 \%$ in uncovered plots and the difference was significant (Table 2). In plots treated with the EOM dose of 9 or $12 \mathrm{ml} / \mathrm{m}^{2}$, the counts increased by 285 and $320 \%$ in covered and by $295 \%$ and $281 \%$ in uncovered plots with no significant difference between the two doses and coverings. However, in plots treated with $18 \mathrm{ml} / \mathrm{m}^{2}$, the increase of $406 \%$ was significantly higher in covered plots, but not in uncovered plots where it increased only by $251 \%$ (Table 2 ). The bacterial counts decreased, from the initial level, by 56 and $84 \%$ in nontreated covered and uncovered plots, respectively, and the difference was significant. In the treated uncovered plots, the bacterial counts were 78 to $80 \%$ lower than the pretreatment counts, without significant difference between untreated and treated plots (Table 2). However, in covered plots, the bacterial counts increased by 73 to $83 \%$ over the pre-treatment counts, but decreased by $57 \%$ in untreated plots. There was no significant difference in bacterial counts of plots treated with different doses of the EOM (Table 2). The CFUs of fungi in non-treated covered plots or plots treated with $9 \mathrm{ml} \mathrm{EOM} / \mathrm{m}^{2}$ decreased by about $40 \%$. However, in plots treated with the dose of 12 or $18 \mathrm{ml} /$ $\mathrm{m}^{2}$, the mean decrease was about $82 \%$ without significant difference between the doses. In the uncovered plots, the CFUs also decreased in a similar pattern, in the range of 31 to $40 \%$ without significant difference between non-treated and treated plots (Table 2).

Although bio-fumigation by green manuring with cruciferous plant species is being widely investigated to substitute MB to control soilborne pathogens, the results are inconsistent. Green manuring with an ecotype of $B$. juncea or Eruca sativa with high glucosinolate content controlled soilborne diseases of strawberry and the yield was similar to methyl bromide treatment (Lazzeri et al., 2003). Despite widely known mode of action involved in controlling soilborne pathogens by green manuring with cruciferous plants, no attempt has been made to study the direct use of the hydrolytic compounds of glucosinolates. The in vitro exposure of the sclerotia of $S$. rolfsii and S. sclerotiorum to the vapors of synthetic EOM showed that it has the potential for use as a fumigant. Like other fumigants, such as MB and chloropicrin, the sclerotial mortality was dependent upon the dose and the exposure period. The mortality was not a onetime event, but a slow process as indicated by the delay in the germination of the sclerotia exposed to the low dose 
TABLE 1 - Hydrolysis of fluorescein diacetate and colony forming units (CFUs) of actinomycetes, bacteria, and fungi in soil with different moisture contents and fumigated for 7 days at $25^{\circ} \mathrm{C}$ with mustard essential oil (MEO) at the rate of $150 \mu 1 / \mathrm{kg}$

\begin{tabular}{|c|c|c|c|}
\hline \multirow{3}{*}{ Treatments } & \multicolumn{3}{|c|}{ Gravimetric moistures" $^{*}$} \\
\hline & Air dry $(2.5 \%)$ & Moist (17\%) & Wet $(22 \%)$ \\
\hline & \multicolumn{3}{|c|}{$\mu \mathrm{g} / \mathrm{g}$ soil hydrolysis of fluorescein diacetate } \\
\hline Control & $49 \pm 2 \mathrm{Aa}$ & $56 \pm 1 \mathrm{Aa}$ & $72 \pm 7 \mathrm{Aa}$ \\
\hline \multirow[t]{2}{*}{ MEO } & $31 \pm 3 \mathrm{Aa}$ & $28 \pm 3 \mathrm{Ba}$ & $38 \pm 9 \mathrm{Ba}$ \\
\hline & \multicolumn{3}{|c|}{ Actinomycetes $\times 10^{5}$} \\
\hline Control & $5 \pm 2 \mathrm{Ac}$ & $41 \pm \mathrm{Aa}$ & $28 \pm 5 \mathrm{Ab}$ \\
\hline \multirow[t]{2}{*}{ MEO 150} & $5 \pm 1 \mathrm{Aa}$ & $2 \pm 2 \mathrm{Ba}$ & $1 \pm 1 \mathrm{Ba}$ \\
\hline & \multicolumn{3}{|c|}{ Bacteria $\times 10^{5}$} \\
\hline Control & $13 \pm 11 \mathrm{Ab}$ & $43 \pm 10 \mathrm{Ba}$ & $37 \pm 12 \mathrm{Aa}$ \\
\hline \multirow[t]{2}{*}{ MEO 150} & $17 \pm 5 \mathrm{Ac}$ & $115 \pm 17 \mathrm{Aa}$ & $43 \pm 9 \mathrm{Ab}$ \\
\hline & \multicolumn{3}{|c|}{ Fungi $\times 10^{4}$} \\
\hline Control & $131 \pm 18 \mathrm{Ab}$ & $187 \pm 13 \mathrm{Aa}$ & $96 \pm 9 \mathrm{Ac}$ \\
\hline MEO 150 & $3 \pm 1 \mathrm{Ba}$ & $3 \pm 2 \mathrm{Ba}$ & $2 \pm 1 \mathrm{Ba}$ \\
\hline
\end{tabular}

${ }^{*}$ For each variable evaluated, means within a column followed by the same uppercase letter or means within a row followed by the same lowercase letter are not significantly different $(P=0.05)$ as determined by Tukey's test.

TABLE 2 - Quantitative changes in the amount of fluorescein diacetate hydrolysis and colony forming units (CFUs) of actinomycetes, bacteria, and fungi in field plots after 7 days of fumigation with the mustard essential oil

\begin{tabular}{|c|c|c|c|}
\hline Concentrations & & Covered & Non-covered \\
\hline \multicolumn{4}{|c|}{$\%$ change hydrolysis } \\
\hline control & $-23 \pm 12 \mathrm{Aa}$ & & $-20 \pm 8 \mathrm{Aa}$ \\
\hline $9 \mathrm{ml} / \mathrm{m}^{2}$ & $-24 \pm 6 \mathrm{Aa}$ & & $-26 \pm 10 \mathrm{Aa}$ \\
\hline $12 \mathrm{ml} / \mathrm{m}^{2}$ & $-38 \pm 8 \mathrm{Aa}$ & & $-27 \pm 9 \mathrm{Aa}$ \\
\hline $18 \mathrm{ml} / \mathrm{m}^{2}$ & $-36 \pm 7 \mathrm{Aa}$ & & $-40 \pm 9 \mathrm{Aa}$ \\
\hline \multicolumn{4}{|c|}{$\%$ change in CFUs of actinomycetes } \\
\hline control & $+222 \pm 46 \mathrm{Ca}$ & & $+120 \pm 37 \mathrm{Bb}$ \\
\hline $9 \mathrm{ml} / \mathrm{m}^{2}$ & $+285 \pm 17 \mathrm{Ba}$ & & $+295 \pm 31 \mathrm{Aa}$ \\
\hline $12 \mathrm{ml} / \mathrm{m}^{2}$ & $+320 \pm 25 \mathrm{Ba}$ & & $+281 \pm 9 \mathrm{Aa}$ \\
\hline $18 \mathrm{ml} / \mathrm{m}^{2}$ & $+406 \pm 28 \mathrm{Aa}$ & & $+251 \pm 25 \mathrm{Ab}$ \\
\hline \multicolumn{4}{|c|}{$\%$ change in CFU of bacteria } \\
\hline control & $-57 \pm 5 \mathrm{Ba}$ & & $-84 \pm 14 \mathrm{Aa}$ \\
\hline $9 \mathrm{ml} / \mathrm{m}^{2}$ & $+74 \pm 28 \mathrm{Aa}$ & & $-80 \pm 24 \mathrm{Ab}$ \\
\hline $12 \mathrm{ml} / \mathrm{m}^{2}$ & $+73 \pm 16 \mathrm{Aa}$ & & $-80 \pm 6 \mathrm{Ab}$ \\
\hline $18 \mathrm{ml} / \mathrm{m}^{2}$ & $+83 \pm 40 \mathrm{Aa}$ & & $-78 \pm 32 \mathrm{Ab}$ \\
\hline \multicolumn{4}{|c|}{ \% change in CFUs of fungi } \\
\hline control & $-40 \pm 15 \mathrm{Aa}$ & & $-31 \pm 9 \mathrm{Aa}$ \\
\hline $9 \mathrm{ml} / \mathrm{m}^{2}$ & $-40 \pm 20 \mathrm{Aa}$ & & $-44 \pm 12 \mathrm{Aa}$ \\
\hline $12 \mathrm{ml} / \mathrm{m}^{2}$ & $-82 \pm 8 \mathrm{Ba}$ & & $-38 \pm 21 \mathrm{Ab}$ \\
\hline $18 \mathrm{ml} / \mathrm{m}^{2}$ & $-83 \pm 13 \mathrm{Ba}$ & & $-31 \pm 30 \mathrm{Ab}$ \\
\hline
\end{tabular}

${ }^{*}$ For each variable evaluated, means within a column followed by the same uppercase letter or means within a row followed by the same lowercase letter are not significantly different $(P=0.05)$ as determined by Tukey's test.

or for short period. Since sclerotia are compact multicellular structures, the delayed germination suggests that not all cells receive effective dose in short exposure period.

The soil tests done in the laboratory and the field plots also showed the potential of the EMO as a fumigant. In these tests, it was applied in the upper few millimeters of soil, and no viable sclerotia were recovered from the entire soil sample collected to the depth of $10 \mathrm{~cm}$. Mortality of the sclerotia of both fungi in air-dry, moist or wet soil at 25 or $35^{\circ} \mathrm{C}$ suggests that the vapors of EOM diffused through the entire soil mass. The fumigant effect was not influenced by soil temperature or moisture prevalent in tropical areas. On the other hand, the data from drip irrigation simulation experiment showed that mortality percent of sclerotia of both fungi decreased with increasing soil depth, but if the applied higher an dose, the sclerotia at deeper sites could 
be killed. This suggests limited diffusion of the EOM in water saturated soil and also its partial retention in the upper soil layers. The use of higher dose allowed for deeper movement of the lethal dose for the sclerotia $S$. rolfsii, but not of S. sclerotiorum.

In the field plots, application of EOM with the use of water as carrier, either significantly reduced the proportion of viable sclerotia or practically killed all sclerotia of $S$. rolfsii, depending upon the dose and plot covering. Despite significant decrease in the proportion of viable sclerotia, a considerable number survived the treatment in uncovered plots regardless of the dose, while practically no viable sclerotia were recovered from covered plots. This suggests containment of the EOM vapors for the effective period in sufficient quantity and also that the plastic covering can considerably reduce the application rate. Even though the half-life of AITC in soil varies from 20 to $60 \mathrm{~h}$ depending upon the soil temperature, being $20 \mathrm{~h}$ at $25^{\circ} \mathrm{C}$ and 22 to $26 \mathrm{~h}$ in dry and wet soil, respectively (Borek et al., 1995), at the application rate of $9 \mathrm{ml} / \mathrm{m}^{2}$ a sufficient quantity was retained even for 7 days of exposure.

Despite the well known biocidal properties of the EOM, data from this study show a non-sterilizing effect. Its toxicity to soil microorganisms appears to be selective. In the laboratory test, the total microbial activity, as measured by FDA hydrolysis, decreased significantly in dry, moist, and wet soil. This decrease was much higher in wet soil, suggesting higher susceptibility of active cells. Since the CFUs of bacteria did not change but those of actinomycetes and fungi decreased by more than $95 \%$, the bacterial population may have the major contribution to FDA hydrolysis. This study did not aim to identify bacterial groups that survived the treatment or were resistant to AITC. The variability among bacterial species for sensitivity to AITC has been reported, with the gram positive bacteria being more resistant than the gram negative ones (Delaquis \& Sholberg 1997; Lin et al., 2000). No significant change in CFUs of actinomyteces in dry compared to the over $95 \%$ declined in moist or wet soil suggests susceptibility of active cells, which depends on the soil moisture. The decline of fungal counts on the other hand was not moisture depended. In the field plots, the change in the total microbial activity was similar in all plots regardless of EOM treatment and covering. CFU counts of actinomycetes, contrary to the laboratory test, increased significantly from the original level, and the quantum depended upon the EOM dose. For example, at the lower dose of 9 or $12 \mathrm{ml} / \mathrm{m}^{2}$, CFU counts increased by 285 to $320 \%$, but with $18 \mathrm{ml} / \mathrm{m}^{2}$ the increase was much higher, reaching $406 \%$. Contrary to the findings of the laboratory study, in covered plots, the bacterial counts increased by about $80 \%$ from the initial level regardless of the dose, but decreased in the uncovered plots, may be due to soil dryness. This increase in CFUs of bacteria and actinomycetes and the decline of fungal counts in covered field plots suggests that the EOM treatment can create a scenario for biological control exploited by actinomycetes and gram positive bacteria.

It can be concluded that the synthetic EOM can be used advantageously as a substitute of bio-fumigation by green manuring with cruciferous plants species and replace MB with similar advantages. The synthetic EOM may also be effective against simpler resting structures of other fungal pathogens.

\section{REFERENCES}

Bending GD, Lincoln SD (1999) Characterisation of volatiles sulphur-containing compounds produced during decomposition of Brassica juncea tissues in soil. Soil Biology and Biochemistry 31:695-703.

Borek V, Morra MJ, Brown PD, Mccaffrey JP (1995) Transformation of the glicosinolate-derived allelochemicals allyl isothiocyanate and allylnitrile in soil. Journal of Agricultural and Food Chemistry 43:1935-1940.

Delaquis PJ, Sholberg PL (1997) Antimicrobial activity of gaseous allyl isothiocyanate. Journal of Food Protection 60:943-947.

Dhingra OD, Costa MLN, Silva Júnior, GJ (2004) Potential of allyl isothiocyanate to control Rhizoctonia solani seedling damping off and seedling blight in transplant production. Journal of Phytopathology 152:352-357.

Dhingra OD, Sinclair JB (1995) Basic Plant Pathology Methods. $2^{\text {nd }}$ Ed. Boca Raton FL, USA. CRC Lewis Publishers.

Lazzeri L, Baruzzi G, Malaguti L, Antoniaccci L (2003) Replacing methyl bromide in annual strawberry production with glucosinolate-containing green manure crops. Pest Management Science 59:983-990.

Lin CM, Preston JF, Wei CI (2000) Bacterial activity of isothiocyanate against pathogens on fresh produce. Journal of Food Protection 63:25-30.

Martin JP (1950) Use of acid, rose bengal, and streptomycin in the plate method for estimating soil fungi. Soil Science 77:197.

Mayton HS, Olivier C, Vaughn SF, Loria ER (1996) Correlation of fungicidal activity of Brassica species with allyl isothiocyanate production in macerated leaf tissue. Phytopathology 86:267-271.

Peres AP, Nasser LCB, Machado JC (2002) Use of semi-seletive media for detection of Sclerotinia sclerotiorum on bean and soybean seeds. Fitopatologia Brasileira 27:123-127.

Schnürer J, Rosswall T (1982) Fluorescein diacetate hydrolysis as a measure of total microbial activity in soil and litter. Applied and Environmental Microbiology 43:1256-1261. 